\title{
RISK PROFILE, GOOD CORPORATE GOVERNANCE, EARNING, CAPITAL (RGEC) METHOD SEBAGAI INSTRUMEN PENGUKUR TINGKAT KESEHATAN PERBANKAN SYARIAH DI INDONESIA
}

\author{
Amir Kusnanto \\ STIE Malangkuçeçwara Malang, Indonesia \\ Email: amirkusnanto@gmail.com
}

\begin{abstract}
Bank Indonesia perfected the Bank's health assessment method from CAMELS to RGEC method which includes factors of Risk Profile, Good Corporate Governance, Earning, and Capital in accordance with Bank Indonesia Circular Letter No.13 / 24 / DPNP dated October 25, 2011 on Assessment Health Level of Commercial Banks. Such adjustments need to be made so that the bank soundness rating can be more effectively used as a tool to evaluate the bank's financial performance. The results of the analysis on the Rating of Health Level at Bank Syariah Mandiri, Bank BRI Syariah, Bank Syariah Bukopin, BCA Syariah using RGEC method shows the bank's health predicate in accordance with the standards set by Bank Indonesia for the period 2013, 2014 and 2015 with the conclusion of the assessment results the same in composite 2, which reflects the general condition of the bank healthy. Except for Bank BNI Syariah in the period of 2013 with the conclusion of composite rating of 1, which reflects the condition of banks that are very healthy, the period 2014 and 2015 with the conclusion of composite rating 2, which reflects the general condition of the bank healthy. The Bank's Health Level in terms of RGEC at Sharia Commercial Banks in the period of 2013, 2014, and 2015 are in healthy criteria, so it is considered very capable of facing significant negative impacts from changes in business conditions and other external factors.

Bank Indonesia menyempurnakan metode penilaian kesehatan bank dari CAMELS menjadi metode RGEC yang meliputi faktor-faktor Risk Profile, Good Corporate Governance, Earning, dan Capital sesuai dengan Surat Edaran (SE) Bank Indonesia No.13/24/DPNP tanggal 25 Oktober 2011 tentang Penilaian Tingkat Kesehatan Bank Umum. Penyesuaian tersebut perlu dilakukan agar penilaian tingkat kesehatan bank dapat lebih efektif digunakan sebagai alat untuk mengevaluasi kinerja keuangan bank. Hasil analisis tentang Penilaian Tingkat Kesehatan pada Bank Syariah Mandiri, Bank BRI Syariah, Bank Syariah Bukopin, BCA Syariah dengan menggunakan metode RGEC menunjukkan predikat kesehatan bank tersebut sesuai dengan standar yang telah ditetapkan oleh Bank Indonesia untuk periode 2013, 2014 dan 2015 dengan kesimpulan hasil penilaian yang sama yaitu pada peringkat komposit 2, yang mencerminkan kondisi bank yang secara umum SEHAT. Kecuali Bank BNI Syariah pada periode 2013 dengan kesimpulan peringkat komposit 1, yang mencerminkan kondisi bank yang secara umum SANGAT SEHAT, periode 2014 dan 2015 dengan kesimpulan peringkat komposit 2, yang mencerminkan kondisi bank yang secara umum SEHAT. Tingkat Kesehatan Bank ditinjau dari RGEC pada Bank Umum Syariah pada periode tahun 2013, 2014, dan 2015 berada pada kriteria sehat, sehingga dinilai sangat mampu menghadapi pengaruh negatif yang signifikan dari perubahan kondisi bisnis dan faktor eksternal lainnya.
\end{abstract}

Keywords:

syariah bank, RGEC, Risk Profile, Good Corporate Governance

Bank syariah, RGEC, Profil Risiko, Tata Pemerintahan yang Baik

\section{Pendahuluan}

Perkembangan bank syariah saat ini sangatlah pesat, baik dilihat dari jumlah pembukaan kantor baru, jenis usaha bank dan volume kegiatan bank yang dilakukan. Hal ini disebabkan adanya penerimaan baik oleh masyarakat dalam sistem lembaga keuangan yang sesuai dengan syariah Islam. Seiring berjalannya waktu, baik perbankan milik pemerintah maupun perbankan milik swasta saling mengembangkan sistem perbankan syariah dan memberikan pelayanan jasa yang beragam untuk meningkatkan minat masyarakat.

Sebagai lembaga keuangan yang mengedepankan kepercayaan masyarakat dan peran sebagai lembaga intermediasi, 
maka bank syariah memerlukan kinerja yang sehat sehingga proses intermediasi dapat berjalan lancar dan tingkat kepercayaan masyarakat meningkat, maka bank harus menunjukkan kinerja yang baik yang tercemin dari laporan keuangan bank. Selain itu diperlukan juga sebuah sistem tata kelola dari masing-masing perbankan agar tetap dapat menjaga tingkat kesehatan bank. Tingkat kesehatan bank merupakan cerminan berhasil atau tidaknya suatu bank dalam menjalankan kegiatan operasionalnya. Bank yang sehat merupakan bank yang dapat melaksanakan fungsinya dengan baik dalam artian bank mampu menghimpun dana dari masyarakat, mengolah dan menyalurkan kemasyarakat dengan baik.

Agar dapat menjalankan fungsinya dengan baik, bank syariah harus memiliki modal yang cukup, menjaga kualitas asetnya dengan baik, dikelola dengan baik dan dioperasikan dengan prinsip kehatihatian, menghasilkan keuntungan yang cukup untuk mempertahankan kelangsungan usahanya, serta memelihara likuiditasnya sehingga dapat memenuhi kewajibannya.

Dalam mengetahui tingkat kesehatan bank maka dilakukan penilaian terhadap kesehatan bank tersebut sesuai dengan Peraturan Bank Indonesia (PBI) agar dapat dikategorikan bank sehat, cukup sehat, kurang sehat atau bahkan tidak sehat. Bagi bank yang teridentifikasi sehat agar tetap mempertahankan kesehatannya, sedangkan bagi bank yang sakit untuk mengobati penyakitnya (Kasmir, 2013:46).

Metode yang sering digunakan untuk menilai kinerja keuangan bank meliputi beberapa faktor yaitu Capital (permodalan), Asset (kualitas aset), Management (manajemen), Earning (rentabilitas), Liquidity (likuiditas) atau disebut metode CAMEL. Selanjutnya metode CAMEL mengalami pengembangan menjadi CAMELS di mana terdapat tambahan Sensitivity terhadap resiko pasar. Selanjutnya, Bank Indonesia menyempurnakan metode penilaian kesehatan bank dari CAMELS menjadi metode RGEC yang meliputi faktor-faktor Risk Profile (profil resiko), Good Corporate Governance (GCG), Earning (rentabilitas), dan Capital (permodalan) sesuai dengan Surat Edaran (SE) Bank Indonesia No.13/24/DPNP tanggal 25 Oktober 2011 tentang Penilaian Tingkat Kesehatan Bank Umum. Penyesuaian tersebut perlu dilakukan agar penilaian tingkat kesehatan bank dapat lebih efektif digunakan sebagai alat untuk mengevaluasi kinerja keuangan bank.

Berdasarkan latar belakang tersebut di atas, maka peneliti tertarik untuk melakukan penelitian kinerja perbankan syariah dengan judul "Risk Profile, Good Corporate Governance, Earning, Capital (RGEC) Method Sebagai Instrumen Pengukur Tingkat Kesehatan Perbankan Syariah di Indonesia".

\section{Kajian Teori}

\section{Kesehatan Bank}

a. Faktor-faktor Penilaian Tingkat Kesehatan Bank dengan Metode RGEC. Peraturan Bank Indonesia No.13/1/PBI/2011 tentang sistem penilaian tingkat kesehatan bank umum, penilaian tingkat kesehatan bank umum mencakup penilaian faktor-faktor sebagai berikut;

1) Profil Risiko

Penilaian terhadap faktor profil risiko sebagaimana dimaksud merupakan penilaian terhadap risiko inheren dan kualitas penerapan manajemen risiko dalam 
operasional bank yang dilakukan terhadap 8 (delapan) risiko yaitu:

a) Risiko kredit

Risiko Kredit adalah risiko akibat kegagalan debitur atau pihak lain dalam memenuhi kewajiban kepada bank seperti pinjaman tidak kembali sesuai dengan kontrak, adanya penundaan, pengurangan pembayaran suku bunga dan pinjaman pokonya, atau tidak membayar pinjamannya sama sekali.

b) Risiko pasar

Suatu risiko yang timbul karena menurunnya nilai suatu investasi karena pergerakan pada faktorfaktor pasar.

c) Risiko likuiditas

Risiko yang antara lain disebabkan bank tidak mampu memenuhi kewajiban yang telah jatuh tempo. Ketidakmampuan bank ini umumnya karena ketidakmampuan offsetting posisi tertentu dengan pasar (karena kondisi likuiditas pasar yang tidak memadai), ketidakmampuan mencairkan aset likuidnya untuk mengubah menjadi dana likuid, ketidakmampuan menciptakan sumber dana pinjaman untuk membiayai likuditas.

d) Risiko opersional

Risiko kerugian yang diakibatkan oleh kegagalan atau tidak memadainya proses internal, kesalahan manusia, kegagalan sistem, atau adanya problem eksternal yang mempengaruhi operasional bank.

e) Risiko hukum

Risiko hukum adalah potensi timbulnya kerugian yang diakibatkan adanya kelemahan aspek yuridis, baik dalam bentuk adanya tuntutan hukum, ketiadaan peraturan perundangan yang mendukung aktivitas atau transaksi kelemahan-kelemahan perikatan yang dilakukan.

f) Risiko stratejik

Risiko yang disebabkan oleh adanya penetapan dan pelaksanaan strategi bank yang tidak tepat atau kurang responsive bank terhadap perubahan eksternal.

g) Risiko kepatuhan

Risiko potensi timbulnya kerugian baik langsung maupun tidak langsung yang diakibatkan oleh tidak dipatuhinya atau tidak dilaksanakannya peraturan perundangan dan ketentuan lain yang berlaku.

h) Risiko reputasi

Merupakan eksposur yang disebabkan adanya publikasi negatif yang terkait dengan kegiatan usaha bank atau persepsi negatif terhadap bank yang dapat mengakibatkan menurunnya tingkat kepercayaan stakeholder.

2) Good Corporate Governance (GCG)

Penilaian terhadap faktor GCG merupakan penilaian terhadap manajemen bank atas pelaksanaan prinsip-prinsip GCG. Dalam ketentuan ini, GCG merupakan suatu tata kelola bank yang menerapkan prinsip-prinsip keterbukaan (transparency), akuntabilitas (accountability), pertanggung jawaban (responsibility), independensi (independency) dan kewajaran (fairness). Dalam ketentuan yang berlaku, setiap bank diwajibkan melakukan penilaian mandiri (self 
assessment) atas pelaksanaan GCG, menyusun laporan pelaksanaan GCG tersebut secara berkala.

3) Earning (Rentabilitas)

Rentabilitas merupakan aspek yang digunakan untuk mengukur kemampuan bank dalam meningkatkan keuntungan. Kemampuan ini dilakukan dalam suatu periode. Pada aspek rentabilitas ini yang dilihat adalah kemampuan bank dalam meningkatkan laba dan efisiensi usaha yang dicapai. Bank yang sehat adalah bank yang diukur secara rentabilitas yang terus meningkat.

4) Capital (Permodalan)

Dalam aspek ini yang dinilai adalah permodalan yang dimiliki oleh bank yang didasarkan kepada kewajiban penyediaan modal minimum bank. Dalam melakukan penilaian kecukupan Permodalan, Bank juga harus mengaitkan kecukupan modal dengan Profil Risiko Bank. Semakin tinggi Risiko Bank, semakin besar modal yang harus disediakan untuk mengantisipasi Risiko tersebut. Penilaian tersebut didasarkan kepada CAR (Capital Adequacy Ratio) yang telah ditetapkan BI. Perbandingan rasio CAR adalah rasio modal terhadap Aktiva Tertimbang Menurut Risiko (ATMR). Sesuai ketentuan yang telah ditetapkan pemerintah, maka CAR perbankan mulai tahun 2002 minimal harus $8 \%$.

\section{Metode Penelitian}

Teknik analisis yang digunakan dalam penelitian adalah menggunakan metode RGEC. Adapun tolok ukur untuk menentukan tingkat kesehatan suatu bank setelah dilakukan penilaian terhadap masing-masing peubah. Analisis deskriptif yang digunakan dalam penelitian untuk menilai tingkat kesehatan bank dengan melakukan penilaian terhadap masing-masing peubah yaitu Risk Profile, Good corporate governance, Earnings dan Capital dengan rasio-rasio keuangan sebagai indikator untuk menentukan hasil penelitian yang kemudian digolongkan menjadi peringkat kesehatan bank pada perusahaan perbankan Syariah yang menjadi sampel pada periode tahun 2013-2015.

Perusahaan Bank Umum Syariah yang dinilai berdasarkan penetapan sample menggunakan Purposive sampling adalah (a) PT. Bank Syariah Mandiri; (b) PT. Bank BRI Syariah; (c) PT. Bank Syariah Bukopin; (d) PT. Bank BNI Syariah; dan (d) PT. BCA Syariah. Setiap faktor penilaian Tingkat Kesehatan Bank ditetapkan peringkatnya berdasarkan kerangka analisis yang komprehensif dan terstruktur. Menghitung peubah-peubah yang digunakan dalam analisis kinerja penilaian terhadap faktor- faktor RGEC yaitu sebagai berikut:

\section{a. Risk Profile}

Risiko yang wajib dinilai terdiri atas 8 jenis risiko yaitu risiko kredit, risiko pasar, risiko likuiditas, risiko operasional, risiko hukum, risiko stratejik, risiko kepatuhan dan risiko reputasi (Hermana, B:2011). Dalam penelitian ini mengukur faktor risk profile dengan menggunakan 3 indikator yaitu faktor risiko kredit dengan menggunakan rumus NPF, risiko likuiditas dengan rumus FDR dan risiko pasar dengan menggunakan IRR.

\section{1) Credit Risk}

Credit Risk adalah risiko yang timbul akibat ketidakmampuan debitur dalam memenuhi kewajibannya terhadap bank. Dalam pengukurannya dengan menggunakan Non Performing 
Financing (NPF) merupakan presentase jumlah kredit bermasalah terhadap total kredit yang disalurkan bank. Semakin rendah rasio ini, maka kemungkinan bank mengalami kerugian sangat rendah yang secara otomatis laba akan semakin meningkat. Rumus untuk menghitung NPF yaitu sebagai berikut :

$\mathrm{NPF}=\frac{\begin{array}{c}\text { Kredit } \\ \text { Bermasalah }\end{array}}{\text { Total Kredit }} \times \quad 100 \%$

\section{2 ) Liquidity Risk}

Liquidity risk adalah risiko yang dihadapi oleh bank karena tidak dapat memenuhi kewajibannya yang telah jatuh tempo dengan harta likuid yang dimilikinya. Dalam penelitian ini liquidity risk diproksikan dengan rasio likuiditas di mana semakin tinggi rasio likuiditas, maka kemungkinan bank mengalami kerugian semakin rendah secara otomatis laba akan semakin meningkat. Penilaian risiko likuiditas dengan menggunakan besaran Financing to Deposit Ratio. Rumus untuk menghitung FDR yaitu sebagai berikut :

$$
\mathrm{FD}=\frac{\text { Total Kredit }}{\begin{array}{c}
\text { Dana Pihak } \\
\text { ketiga }
\end{array}} \times \quad \begin{gathered}
100 \\
\%
\end{gathered}
$$

\section{3) Market Risk}

Market Risk merupakan rasio yang timbul karena adanya pergerakan peubah pasar. Dalam menilai resiko inheren atas resiko pasar parameter yang digunakan adalah risiko suku bunga dalam Banking book (Interest Rate Risk Ratio in Banking book IRRBB) berdasarkan Gap Report. Gap Report merupakan laporan yang menyajikan pos-pos aset dan kewajibandan rekening administratif yang bersifat interest rate sensitive. Neraca suatu bank ada da sisi yaitu asset dan liability, masingmasing sensitive terhadap perubahn tingkat bunga. Sensitifitas di sisi asset disebut Rate Sensitive Assets (RSA) dan di sisi liability disebut Rate Sensitive Liability (RSL). Jika pos-pos tersebut tidak dikelola denga baik, pendapatan neto bunga akan menurun (Kusnanto, A. 2015:29). Pengukurannya rasio sensitivitas bunga yang merupakan perbandingan antara RSA terhadap RSL:

IRR $=\frac{\begin{array}{c}\text { Rate Sensitive } \\ \text { Assets }\end{array}}{\begin{array}{c}\text { Rate Sensitive } \\ \text { Liabilities }\end{array}} \quad 100 \%$

b. Good corporate governance

Penetapan peringkat faktor GCG dilakukan berdasarkan analisis yang komprehensif dan terstruktur terhadap hasil penilaian pelaksanaan prinsipprinsip GCG Bank dan informasi lain yang terkait dengan GCG bank. Penetapan peringkat faktor GCG secara konsolidasi dilakukan dengan memperhatikan:

a) Signifikansi atau materialitas pangsa Perusahaan Anak terhadap bank secara konsolidasi, dan/atau

b) Permasalahan terkait dengan pelaksanaan prinsip-prinsip GCG pada Perusahaan Anak yang berpengaruh secara signifikan terhadap pelaksanaan prinsipprinsip GCG.

Penilaian terhadap faktor GCG menggunakan sistem self assessment di mana masing- masing Bank menghitung sendiri komponen GCG mereka berdasarkan PBI No.13/PBI/2011 yang terdiri dari 11 aspek penilaian. 
Tabel 1. Aspek Penilaian Good Corporate Governance (GCG)

\begin{tabular}{|l|c|}
\hline \multicolumn{1}{|c|}{ Aspek Penilaian } & Bobot \\
\hline $\begin{array}{l}\text { Pelaksanaan Tugas dan } \\
\text { Tanggung Jawab Dewan }\end{array}$ & $10 \%$ \\
\hline $\begin{array}{l}\text { Pelaksanaan Tugas dan } \\
\text { Tanggung Jawab Direksi }\end{array}$ & $20 \%$ \\
\hline Kelengkapan dan Pelaksanaan & $10 \%$ \\
\hline Penanganan Benturan & $10 \%$ \\
\hline Penerapan Fungsi Kepatuhan & $5 \%$ \\
\hline Penerapan Fungsi Audit Intern & $5 \%$ \\
\hline Penerapan Fungsi Audit Ekstern & $5 \%$ \\
\hline $\begin{array}{l}\text { Penerapan Fungsi Manajemen } \\
\text { Risiko dan Pengendalian Intern }\end{array}$ & $7,5 \%$ \\
\hline $\begin{array}{l}\text { Penyediaan Dana Kepada Pihak } \\
\text { Terkait (Related Party) dan } \\
\text { Debitur Besar (Large Exposure) }\end{array}$ & $7,5 \%$ \\
\hline $\begin{array}{l}\text { Transparasi Kondisi Keuangan } \\
\text { dan Non Keuangan Bank, } \\
\text { Laporan Pelaksanaan GCG dan }\end{array}$ & $15 \%$ \\
\hline Rencana Strategis Bank & $5 \%$ \\
\hline
\end{tabular}

\section{c. Earnings (Rentabilitas)}

Penetapan peringkat penilaian faktor rentabilitas secara konsolidasi dilakukan berdasarkan analisis secara komprehensif dan terstruktur terhadap parameter atau indikator rentabilitas tertentu yang dihasilkan dari laporan keuangan bank secara konsolidasi dan informasi keuangan lainnya yang mempengaruhi permodalan bank. Rasio keuangan penilaian rentabilitas ini meliputi:

\section{1) Return on Asset (ROA)}

ROA adalah rasio yang digunakan mengukur kemampuan bank menghasilkan keuntungan secara relatif dibandingkan dengan total asetnya. Rasio ini mengukur kemampuan perusahaan menghasilkan laba bersih berdasarkan tingkat aset tertentu. Semakin besar ROA, semakin besar pula tingkat keuntungan (laba) yang dicapai bank (positif).

\section{2) Net Interest Margin (NIM)}

Rasio ini digunakan untuk mengukur kemampuan kinerja manajemen bank dalam menyalurkan kredit, mengingat pendapatan operasional bank sangat bergantung dari selisih antara suku bunga dari kredit yang disalurkan dengan suku bunga simpanan yang diterima (pendapatan bunga bersih). NIM merupakan perbandingan antara pendapatan bunga bersih terhadap rata-rata aktiva produktif. Semakin tinggi rasio ini, menunjukkan kemungkinan laba bank akan meningkat (positif).

\section{d. Capital (Permodalan)}

Penetapan peringkat penilaian faktor permodalan Bank secara konsolidasi dilakukan berdasarkan analisis secara komprehensif dan terstruktur terhadap parameter/indikator permodalan tertentu yang dihasilkan dari laporan keuangan Bank secara konsolidasi dan informasi keuangan lainnya. Rasio untuk menilai permodalan adalah Capital Adequacy Ratio. Capital Adequacy Ratio (CAR) adalah rasio yang memperlihatkan seberapa jumlah seluruh aktiva bank yang mengandung unsur risiko (kredit, penyertaan, surat berharga, tagihan pada bank lain) yang ikut dibiayai dari modal sendiri disamping memperoleh dana-dana dari sumber-sumber diluar bank. Semakin tinggi CAR berarti semakin tinggi modal sendiri untuk mendanai aktiva produktif, semakin rendah biaya dana yang dikeluarkan oleh bank. Semakin rendah biaya dana maka semakin meningkatkan laba bank.

Peringkat Komposit Tingkat Kesehatan Bank yang ditetapkan 
dalam metode ini berdasarkan analisis secara komprehensif dan terstruktur terhadap peringkat setiap faktor : profil risiko, GCG, rentabilitas, dan permodalan dengan memperhatikan materialitas dan signifikansi masingmasing faktor.

Berdasarkan PBI No. 13/1/PBI/2011 Peringkat Komposit dikategorikan sebagai berikut:

a. Peringkat Komposit 1 (PK-1), mencerminkan kondisi Bank yang secara umum sangat sehat, sehingga dinilai sangat mampu menghadapi pengaruh negatif yang signifikan dari perubahan kondisi bisnis dan faktor eksternal.

b. Peringkat Komposit 2 (PK-2), mencerminkan kondisi Bank yang secara umum sehat sehingga dinilai sangat mampu menghadapi pengaruh negatif yang signifikan dari perubahan kondisi bisnis dan faktor eksternal lainnya.

c. Peringkat Komposit 3 (PK-3), mencerminkan kondisi Bank yang secara umum cukup sehat, sehingga dinilai sangat mampu menghadapi pengaruh negatif yang signifikan dari perubahan kondisi bisnis dan faktor eksternal lainnya.

d. Peringkat Komposit 4 (PK-4), mencerminkan kondisi Bank yang secara umum kurang sehat, sehingga dinilai sangat mampu menghadapi pengaruh negatif yang signifikan dari perubahan kondisi bisnis dan faktor eksternal lainnya.

e. Peringkat Komposit 5 (PK-5), mencerminkan kondisi Bank yang secara umum tidak sehat sehingga dinilai sangat mampu menghadapi pengaruh negatif yang signifikan dari perubahan kondisi bisnis dan faktor eksternal lainnya.

\section{Hasil dan Pembahasan}

1. Penetapan Peringkat Penilaian Tingkat Kesehatan Bank Syariah Mandiri dengan metode RGEC.

Profil risiko Bank Syariah Mandiri termasuk peringkat 2, artinya kemungkinan kerugian yang dihadapi bank dari risiko inheren komposit tergolong rendah selama periode waktu tertentu. Kualitas penerapan manajemen risiko secara komposit memadai dengan rasio NPF, FDR dan IRR msing-masing rasio 3,00\%, 89,88\% dan $101,51 \%$. Pelaksanaan GCG berada pada peringkat 2 yang secara umum berarti baik. Peringkat faktor rentabilitas memadai, karena laba melebihi target dan mendukung pertumbuhan permodalan Bank yang dinyatakan dengan rasio ROA dan NIM dengan rasio masing-masing sebesar $1,50 \%$ dan $6,13 \%$. Peringkat faktor permodalan menunjukkan peringkat 2 yang artinya bank memiliki kualitas dan kecukupan permodalan yang memadai relatif terhadap profil risikonya, yang disertai dengan pengelolaan permodalan yang kuat, yang ditunjukkan dengan rasio CAR sebesar $14,10 \%$. Profil risiko Bank Syariah Mandiri termasuk peringkat 2, artinya kemungkinan kerugian yang dihadapi bank dari risiko inheren komposit tergolong rendah selama periode waktu tertentu. Kualitas penerapan manajemen risiko secara komposit memadai dengan rasio NPF, FDR dan IRR msing-masing rasio 3,51\%, $82,73 \%$ dan $172,38 \%$. Pelaksanaan GCG berada pada peringkat 2 yang secara umum berarti baik. Peringkat faktor rentabilitas cukup memadai, karena terjadi kerugian sehingga tidak tercapainnya laba dan mengurangi pertumbuhan permodalan Bank yang dinyatakan dengan rasio ROA dan NIM dengan rasio masing-masing sebesar $0,04 \%$ dan $5,02 \%$. Peringkat faktor permodalan menunjukkan peringkat 2 , 
yang artinya bank memiliki kualitas dan kecukupan permodalan yang memadai relatif terhadap profil risikonya, disertai pengelolaan permodalan yang kuat, yang ditunjukkan dengan rasio CAR sebesar $14,12 \%$.

Profil risiko Bank Syariah Mandiri termasuk peringkat 2, berarti kemungkinan kerugian yang dihadapi bank dari risiko inheren komposit tergolong rendah selama periode waktu tertentu. Kualitas penerapan manajemen risiko secara komposit memadai dengan rasio NPF, FDR dan IRR masing-masing rasio $3,95 \%, 83,06 \%$ dan $152,55 \%$. Pelaksanaan GCG bank berada pada peringkat 1 yang berarti sangat baik. Peringkat faktor rentabilitas memadai, karena laba melebihi target dan mendukung pertumbuhan permodalan Bank yang dinyatakan dengan rasio ROA dan NIM dengan rasio masing-masing sebesar $0,54 \%$ dan 5,55\%. Peringkat faktor permodalan menunjukkan peringkat 2 yang artinya bank memiliki kualitas dan kecukupan permodalan yang memadai relatif terhadap profil risikonya, dengan CAR 12,85\%. Nilai rasio RGEC Bank Syariah Mandiri tahun 2013, 2014, dan 2015 menunjukkan predikat kesehatan bank tersebut sesuai dengan standar yang telah ditetapkan oleh Bank Indonesia dengan kesimpulan peringkat komposit 2, yang mencerminkan kondisi bank secara umum sehat, sehingga dinilai mampu menghadapi pengaruh negatif yang signifikan dari perubahan kondisi bisnis dan faktor eksternal lainnya.

\section{Penetapan Peringkat Penilaian Tingkat Kesehatan Bank BRI Syariah dengan metode RGEC.}

\footnotetext{
Profil risiko Bank BRI Syariah termasuk peringkat 2, artinya kemungkinan kerugian yang dihadapi bank dari risiko inheren komposit tergolong rendah selama periode waktu tertentu. Kualitas penerapan manajemen
}

risiko secara komposit memadai dengan rasio NPF, FDR dan IRR msing-masing rasio $1,73 \%, 102,70 \%$ dan $47,00 \%$. Pelaksanaan GCG mencerminkan bahwa penerapan GCG bank berada pada peringkat 1 yang secara umum berarti sangat baik. Peringkat faktor rentabilitas memadai, karena laba melebihi target dan mendukung pertumbuhan permodalan Bank yang dinyatakan dengan rasio ROA dan NIM dengan rasio masing-masing sebesar $1,17 \%$ dan $6,57 \%$. Peringkat faktor permodalan menunjukkan peringkat 2 yang artinya bank memiliki kualitas dan kecukupan permodalan yang memadai relatif terhadap profil risikonya, dengan Profil risiko Bank BRI Syariah termasuk peringkat 2, karena mempertimbangkan aktivitas bisnis yang dilakukan oleh bank, kemungkinan kerugian yang dihadapi bank dari risiko inheren komposit tergolong rendah selama periode waktu tertentu dimasa datang dan kualitas penerapan manajemen risiko secara komposit memadai dengan rasio NPF, FDR dan IRR msing-masing rasio $1,76 \%, 93,90 \%$ dan $64,04 \%$. Pelaksanaan GCG mencerminkan bahwa penerapan GCG bank berada pada peringkat 2 yang secara umum berarti baik. Peringkat faktor rentabilitas memadai, karena laba melebihi target dan mendukung pertumbuhan permodalan Bank yang dinyatakan dengan rasio ROA dan NIM dengan rasio masing-masing sebesar $0,05 \%$ dan $6,02 \%$. Peringkat faktor permodalan menunjukkan peringkat 2 yang artinya bank memiliki kualitas dan kecukupan permodalan yang memadai relatif terhadap profil risikonya, yang disertai dengan pengelolaan permodalan yang kuat, yang ditunjukkan dengan rasio CAR sebesar $12,89 \%$.

Profil risiko Bank BRI Syariah termasuk peringkat 2, karena mempertimbangkan aktivitas bisnis yang dilakukan oleh bank, kemungkinan kerugian yang dihadapi bank dari risiko 
inheren komposit tergolong rendah selama periode waktu tertentu. Kualitas penerapan manajemen risiko secara komposit memadai dengan rasio NPF, FDR dan IRR msing-masing rasio 2,22\%, $84,79 \%$ dan 94,10\%. Pelaksanaan GCG mencerminkan bahwa penerapan GCG bank berada pada peringkat 2 yang secara umum berarti baik. Peringkat faktor rentabilitas memadai, karena laba melebihi target dan mendukung pertumbuhan permodalan Bank yang dinyatakan dengan rasio ROA dan NIM dengan rasio masing-masing sebesar $0,76 \%$ dan $6,54 \%$. Peringkat faktor permodalan menunjukkan peringkat 2 yang artinya bank memiliki kualitas dan kecukupan permodalan yang memadai relatif terhadap profil risikonya, yang disertai dengan pengelolaan permodalan yang kuat, yang ditunjukkan dengan rasio CAR sebesar $13,94 \%$.

Nilai rasio RGEC tahun 2013, 2014 dan 2015 menunjukkan predikat kesehatan bank tersebut sesuai dengan standar yang telah ditetapkan oleh Bank Indonesia dengan kesimpulan peringkat komposit 2, yang mencerminkan kondisi bank yang secara umum sehat, sehingga dinilai mampu menghadapi pengaruh negatif yang signifikan dari perubahan kondisi bisnis dan faktor eksternal lainnya.

\section{3). Penetapan Peringkat Penilaian} Tingkat Kesehatan Bank Syariah Bukopin dengan metode RGEC.

Profil risiko Bank Syariah Bukopin termasuk peringkat 2, artinya kemungkinan kerugian yang dihadapi bank dari risiko inheren komposit tergolong rendah selama periode waktu tertentu . Kualitas penerapan manajemen risiko secara komposit memadai dengan rasio NPF, FDR dan IRR msing-masing rasio $2,07 \%, 100,29 \%$ dan 58,60\%. Penerapan GCG bank berada pada peringkat 2 yang secara umum berarti baik. Peringkat faktor rentabilitas memadai, karena laba melebihi target dan mendukung pertumbuhan permodalan Bank yang dinyatakan dengan rasio ROA dan NIM dengan rasio masing-masing sebesar $0,68 \%$ dan $3,81 \%$. Peringkat faktor permodalan menunjukkan peringkat 2 yang artinya bank memiliki kualitas dan kecukupan permodalan yang memadai relatif terhadap profil risikonya, CAR sebesar $14,80 \%$.

Profil risiko Bank Syariah Bukopin termasuk peringkat 2, karena mempertimbangkan aktivitas bisnis yang dilakukan oleh bank, kemungkinan kerugian yang dihadapi bank dari risiko inheren komposit tergolong rendah selama periode waktu tertentu dimasa datang dan kualitas penerapan manajemen risiko secara komposit memadai dengan rasio NPF, FDR dan IRR msing-masing rasio $1,64 \%, 92,89 \%$ dan $72,59 \%$. Pelaksanaan GCG mencerminkan bahwa penerapan GCG bank berada pada peringkat 2 yang secara umum berarti baik. Peringkat faktor rentabilitas cukup memadai, karena terjadi kerugian sehingga tidak tercapainnya laba dan mengurangi pertumbuhan permodalan Bank yang dinyatakan dengan rasio ROA dan NIM dengan rasio masing-masing sebesar $0,26 \%$ dan 2,98\%. Peringkat faktor permodalan menunjukkan peringkat 2 yang artinya bank memiliki kualitas dan kecukupan permodalan yang memadai relatif terhadap profil risikonya, dengan rasio CAR sebesar $14,80 \%$.

Profil risiko Bank Syariah Bukopin termasuk peringkat 2, yang berarti kemungkinan kerugian yang dihadapi bank dari risiko inheren komposit tergolong rendah selama periode waktu tertentu dimasa datang dan kualitas penerapan manajemen risiko secara komposit memadai dengan rasio NPF, FDR dan IRR msing-masing rasio $1,61 \%$, 90,56\% dan 76,78\%. Pelaksanaan GCG mencerminkan bahwa penerapan GCG 
bank berada pada peringkat 2 yang secara umum berarti baik. Peringkat faktor rentabilitas memadai, karena laba melebihi target dan mendukung pertumbuhan permodalan Bank yang dinyatakan dengan rasio ROA dan NIM dengan rasio masing-masing sebesar $0,74 \%$ dan $3,21 \%$. Peringkat faktor permodalan menunjukkan peringkat 1 yang artinya bank memiliki kualitas dan kecukupan permodalan yang sangat memadai relatif terhadap profil risikonya, dengan rasio CAR sebesar 16,31\%.

Nilai rasio RGEC Bank Bukopin Syariah tahun 2013, 2014, dan 2015 menunjukkan predikat kesehatan bank tersebut sesuai dengan standar yang telah ditetapkan oleh Bank Indonesia dengan kesimpulan peringkat komposit 2, yang mencerminkan kondisi bank yang secara umum sehat, sehingga dinilai mampu menghadapi pengaruh negatif yang signifikan dari perubahan kondisi bisnis dan faktor eksternal lainnya.

\section{4) Penetapan Peringkat Penilaian Tingkat Kesehatan Bank BNI Syariah dengan metode RGEC.}

\section{Profil risiko Bank BNI Syariah} termasuk peringkat 2, karena mempertimbangkan aktivitas bisnis yang dilakukan oleh bank, kemungkinan kerugian yang dihadapi bank dari risiko inheren komposit tergolong rendah selama periode waktu tertentu dimasa datang dan kualitas penerapan manajemen risiko secara komposit memadai dengan rasio NPF, FDR dan IRR msing-masing rasio $1,70 \%, 98,42 \%$ dan $60,84 \%$. Pelaksanaan GCG bank berada pada peringkat 1 yang secara umum berarti sangat baik. Peringkat faktor rentabilitas sangat memadai, karena laba melebihi target dan mendukung pertumbuhan permodalan Bank yang dinyatakan dengan rasio ROA dan NIM dengan rasio masing-masing sebesar $1,42 \%$ dan $7,81 \%$. Peringkat faktor permodalan menunjukkan peringkat 1 yang artinya bank memiliki kualitas dan kecukupan permodalan yang sangat memadai relatif terhadap profil risikonya dengan CAR sebesar $16,23 \%$.

Profil risiko Bank BNI Syariah termasuk peringkat 2, artinya kemungkinan kerugian yang dihadapi bank dari risiko inheren komposit tergolong rendah selama periode waktu tertentu. Kualitas penerapan manajemen risiko secara komposit memadai dengan rasio NPF, FDR dan IRR msing-masing rasio 1,69\%, $92,58 \%$ dan $83,65 \%$. Pelaksanaan GCG bank berada pada peringkat 2 yang secara umum berarti baik. Peringkat faktor rentabilitas sangat memadai, karena laba melebihi target dan mendukung pertumbuhan permodalan Bank dengan rasio ROA dan NIM dengan rasio masingmasing sebesar $1,29 \%$ dan $8,60 \%$. Peringkat faktor permodalan menunjukkan peringkat 1 yang artinya bank memiliki kualitas dan kecukupan permodalan yang sangat memadai relatif terhadap profil risikonya, dengan CAR sebesar 18,42.

Profil risiko Bank BNI Syariah termasuk peringkat 2, karena mempertimbangkan aktivitas bisnis yang dilakukan oleh bank, kemungkinan kerugian yang dihadapi bank dari risiko inheren komposit tergolong rendah selama periode waktu tertentu dimasa datang dan kualitas penerapan manajemen risiko secara komposit memadai dengan rasio NPF, FDR dan IRR msing-masing rasio 2,14\%, 91,93\% dan 104\%. Pelaksanaan GCG bank berada pada peringkat 2 yang secara umum berarti baik. Peringkat faktor rentabilitas sangat memadai, karena laba melebihi target dan mendukung pertumbuhan permodalan Bank yang dinyatakan dengan rasio ROA dan NIM dengan rasio masing-masing sebesar $1,45 \%$ dan $8,40 \%$. Peringkat faktor permodalan menunjukkan peringkat 1 yang artinya bank memiliki kualitas dan kecukupan permodalan yang 
sangat memadai relatif terhadap profil risikonya, dengan rasio CAR sebesar $15,48 \%$.

Nilai rasio RGEC Ban BNI Syariah tahu 2013, 2014 dan 2015 menunjukkan predikat kesehatan bank tersebut sesuai dengan standar yang telah ditetapkan oleh Bank Indonesia dengan kesimpulan peringkat komposit 2, yang mencerminkan kondisi bank yang secara umum sehat, sehingga dinilai mampu menghadapi pengaruh negatif yang signifikan dari perubahan kondisi bisnis dan faktor eksternal lainnya.

\section{5). Penetapan Peringkat Penilaian Tingkat Kesehatan Bank BCA Syariah dengan metode RGEC}

$\begin{array}{cccc}\text { Profil risiko Bank } & \text { BCA } & \text { Syariah } \\ \text { termasuk } & \text { peringkat } & 2, & \text { artinya }\end{array}$
kemungkinan kerugian yang dihadapi bank dari risiko inheren komposit tergolong rendah selama periode waktu tertentu dimasa datang dan kualitas penerapan manajemen risiko secara komposit memadai dengan rasio NPF, FDR dan IRR msing-masing rasio 3,69\%, $85,69 \%$ dan $119,38 \%$. Pelaksanaan GCG mencerminkan bahwa penerapan GCG bank berada pada peringkat 2 yang secara umum berarti baik. Peringkat faktor rentabilitas memadai, dengan rasio ROA dan NIM sebesar $0,92 \%$ dan 4,66\%. Peringkat faktor permodalan menunjukkan peringkat 1 yang artinya bank memiliki kualitas dan kecukupan permodalan yang sangat memadai relatif terhadap profil risikonya, disertai rasio CAR sebesar $22,28 \%$.

Profil risiko Bank BCA Syariah termasuk peringkat 2, karena mempertimbangkan aktivitas bisnis yang dilakukan oleh bank, kemungkinan kerugian yang dihadapi bank dari risiko inheren komposit tergolong rendah selama periode waktu tertentu . Kualitas penerapan manajemen risiko secara komposit memadai dengan rasio NPF,
FDR dan IRR msing-masing rasio 3,20\%, 93,36\% dan 92,26\%. Pelaksanaan GCG bank berada pada peringkat 1 yang secara umum berarti sangat baik. Peringkat faktor rentabilitas memadai, dengan rasio ROA dan NIM masing-masing sebesar $0,69 \%$ dan $3,95 \%$. Peringkat faktor permodalan menunjukkan peringkat 1 yang artinya bank memiliki kualitas dan kecukupan permodalan yang sangat memadai relatif terhadap profil risikonya, dengan CAR sebesar 29,57\%.

Profil risiko Bank BCA Syariah termasuk peringkat 2, artinya kemungkinan kerugian yang dihadapi bank dari risiko inheren komposit tergolong rendah selama periode waktu tertentu. Penerapan manajemen risiko secara komposit memadai dengan rasio NPF, FDR dan IRR msing-masing rasio $3,65 \%, 93,61 \%$ dan $98,31 \%$. Pelaksanaan GCG bank berada pada peringkat 1 yang secara umum berarti sangat baik. Peringkat faktor rentabilitas memadai, dengan rasio ROA dan NIM dengan rasio masing-masing sebesar $0,87 \%$ dan $4,66 \%$. Peringkat faktor permodalan menunjukkan peringkat 1 yang artinya bank memiliki kualitas dan kecukupan permodalan yang sangat memadai relatif terhadap profil risikonya, dengan rasio CAR sebesar $34,33 \%$.

Nilai rasio RGEC Bank BCA Syariah tahun 2013, 2014, dan 2015 menunjukkan predikat kesehatan bank tersebut sesuai dengan standar yang telah ditetapkan oleh Bank Indonesia dengan kesimpulan peringkat komposit 2, yang mencerminkan kondisi bank yang secara umum sehat, sehingga dinilai mampu menghadapi pengaruh negatif yang signifikan dari perubahan kondisi bisnis dan faktor eksternal lainnya.

Dalam Penilaian Tingkat kesehatan pada Bank Umum Syariah di Indonesia yang telah diwakili oleh lima Bank Umum Syariah yang beroperasi di 
Indonesia yaitu Bank Syariah Mandiri, Bank BRI Syariah, Bank Syariah Bukopin, Bank BNI Syariah dan Bank BCA Syariah dengan pendekatan RGEC dapat dikatakan bahwa penilaian relatif semua bank dalam kondisi Sehat.

\section{Kesimpulan dan Saran}

\section{Kesimpulan}

Berdasarkan pengolahan dan analisis data hasil penelitian dapat disimpulkan sebagai berikut:

1. Penilaian Tingkat Kesehatan pada Bank Syariah Mandiri dengan menggunakan metode RGEC menunjukkan predikat kesehatan bank sesuai dengan standar yang telah ditetapkan oleh Bank Indonesia untuk periode 2013, 2014 dan 2015 dengan kesimpulan hasil penilaian yang sama yaitu pada peringkat komposit 2, yang mencerminkan kondisi bank yang secara umum SEHAT.

2. Penilaian Tingkat Kesehatan pada Bank BRI Syariah dengan menggunakan metode RGEC menunjukkan predikat kesehatan bank sesuai dengan standar yang telah ditetapkan oleh Bank Indonesia untuk periode 2013, 2014 dan 2015 dengan kesimpulan hasil penilaian yang sama yaitu pada peringkat komposit 2, yang mencerminkan kondisi bank yang secara umum SEHAT.

3. Penilaian Tingkat Kesehatan Bank Syariah Bukopin dengan menggunakan metode RGEC menunjukkan predikat kesehatan bank sesuai dengan standar yang telah ditetapkan oleh Bank Indonesia untuk periode 2013, 2014 dan 2015 dengan kesimpulan hasil penilaian yang sama yaitu pada peringkat komposit 2, yang mencerminkan kondisi bank yang secara umum SEHAT.
4. Penilaian Tingkat Kesehatan Bank BNI Syariah dengan menggunakan metode RGEC menunjukkan predikat kesehatan bank tersebut sesuai dengan standar yang telah ditetapkan oleh Bank Indonesia untuk periode 2013 dengan kesimpulan peringkat komposit 1, yang mencerminkan kondisi bank yang secara umum SANGAT SEHAT, periode 2014 dan 2015 dengan kesimpulan peringkat komposit 2, yang mencerminkan kondisi bank yang secara umum SEHAT.

5. Penilaian Tingkat Kesehatan Bank BCA Syariah dengan menggunakan metode RGEC menunjukkan predikat kesehatan bank tersebut sesuai dengan standar yang telah ditetapkan oleh Bank Indonesia untuk periode 2013, 2014 dan 2015 dengan kesimpulan hasil penilaian yang sama yaitu pada peringkat komposit 2, yang mencerminkan kondisi bank yang secara umum SEHAT.

6. Tingkat Kesehatan Bank ditinjau dari aspek risk profile, earnings, good corporate governance, dan capital, kelima Bank Umum Syariah tersebut di atas periode tahun 2013, 2014, dan 2015 berada pada kriteria sehat, sehingga dinilai sangat mampu menghadapi pengaruh negatif yang signifikan dari perubahan kondisi bisnis dan faktor eksternal lainnya.

\section{Saran-saran}

a. Bank Umum Syariah hendaknya memperhatikan dan menjaga tingkat kesehatan banknya dengan prinsip kehati-hatian yang selalu memperhatikan risiko-risiko keuangan yang mungkin akan terjadi. Hal ini dikarenakan, tingkat kesehatan bank menggambarkan kinerja keuangan yang ada di dalam bank tersebut. Dengan menjaga tingkat kesehatan bank, Bank Umum Syariah tentunya dapat meningkatkan 
kemampuan aset, pengelolaan modal, serta pendapatan operasional. Hal ini akan meningkatkan kualitas laba meningkatkan

kepercayaan stakeholders.

b. Mempertahankan kesehatan bank untuk tahun-tahun berikutnya tidak hanya berfokus pada laporan keuangan, tetapi Bank Umum Syariah perlu juga untuk mengembangkan usaha dengan pelayanan yang diberikan lebih aman, mudah, dan juga cepat.

c. Bagi peneliti selanjutnya, disarankan untuk memperluas cakupan penelitian tentang analisis tingkat kesehatan bank dengan menggunakan indikator rasio keuangan lainnya pada pengukuran tingkat kesehatan bank dengan metode yang terbaru sesuai dengan Surat Edaran Bank Indonesia atau dari Otoritas Jasa Keuangan.

\section{Daftar Referensi}

Bank Indonesia. 2011. "Peraturan Bank Indonesia Nomor 13/1/PBI/2011 Tanggal 5 Januari 2011 Tentang Penilaan Tingkat Kesehatan Bank Umum", diakses pada 1 Agustus 2016 dari www.bi.go.id/id/peraturan/perbanka n/Documents/828aa23594154a89aea bab7dc3103805pbi_130112.pdf

Bank Indonesia. 2011. "Surat Edaran

No.13/24/DPNP Tanggal 25

Oktober 2011 Tentang Penilaian

Tingkat Kesehatan BankUmum", diakses pada Tanggal 17 September 2016

dari

http://www.bi.go.id/id/peraturan/per

bankan/Documents/

7560419573a843e886aea5e2aecc0c 49SENo13_24_DPNP.pdf

Kasmir. 2013. Dasar-Dasar Perbankan. Jakarta. PT Raja Grafindo Persada.
Kusnanto, Amir. 2015. Manajemen Aset dan Likuiditas. Malang. Badan Penerbit STIE Malangkucecwara. 